\title{
The Fast and the Negative: Dialectics and Posthumanism
}

\author{
LJUBISHA PETRUSHEVSKI \\ Euro College, Done Bozinov 41, 1300, Kumanovo, North Macedonia \\ Email: ljubisha@eurocollege.edu.mk
}

\begin{abstract}
The article refers to the way the recent TV drama Brexit: The Uncivil War deconstructs the inherent contradictions of modern capitalism. Historically, both Marx and the avant-garde believed that acceleration or deceleration will aggravate the contradictions to the point of the collapse of the system. British cultural theory further expounds this issue by adding a curious philosophical perspective of the way capital deals with the abstraction of the real in the digital era. Their take on accelerationism subsequently created two competing aesthetic and political concepts: the left wing that endeavours to exploit the dialectical negativity in order to re-purpose the technological speed away from capital's imaginary, and the right wing that embraces the acceleration of the forces of production to disclose the invasion of posthuman, machinistic Singularity.
\end{abstract}

Keywords: avant-garde, Marx, Nick Land, Brexit, accelerationism, real abstraction

\section{INTRODUCTION}

The lesson learned from the latest financial crash was that, once again, capital moves faster than capitalism. For Marx, the root of the problem lies in the inherent contradictions in the organization of the capitalist world, between the mode of production and its social relation. We are living in the age when the forces of the financial trading lack substantial support from the suitable social infrastructure. The speed is the vital factor and it threatens everyone. The need for speed is considered to be the vestige of the modernist experience. From late 17th century onwards there have been several important transitional periods when the temporal pace of the emerging technologies and financial markets was not duly synchronized with the rhythm of the empirical historical time of the society. The object of this study is the history of accelerationism, accompanying every major technological revolution and the abstraction of the reality as the resulting effect of this process. The recourse to critical theory might be useful to expose such concepts and contradictions in historical perspective, as perceived by Marx, the avant-garde and the modern British philosophy.

Marx (2010) considered the process of abstraction vital for the establishment of the value relations in the market economy. The provisional relation between the value of the labour and the commodity price, 'the real abstraction', is instrumental in the creation of the smooth capitalist space that enables the extraction of the surplus value and profit from the abstracted unpaid, dead labour. Alfred Sohn Rethel (1978), the Frankfurt school and currently Finneli 
(2007) and Toscano (2008) analysed various aspects of the way abstraction supports the capital expansion. Guy Debord $(1994,1998)$ invented the term spectacle to reflect on the advanced level of abstraction as a result of the technological developments of mid-20th century capitalism. Jean Badrillard (1988) chose the term simulation to describe its postmodern use. British Cultural Studies added further contributions: from the dystopian philosophical concept of cyberpositive and hyperstition of Nick Land (1995) and Sadie Plant (1992) to the retro-SI use of the concept by Benjamin Noys (2010).

The concept of accelerationism also stemmed from Marx's criticism of the operations of the capital. Marx propagated the class revolution that will allow the masses to start creating their own lives. To achieve this, the old system had to be accelerated into a flux until the social revolution establishes the just society. At the beginning of the 20th century, it was the European avant-garde movements that tried to exploit the newly produced social contradictions. As a result, Italian Futurism demanded immediate acceleration of the society. Marinetti announced that 'the beauty of the world has been enriched by a new form of beauty: the beauty of speed'. (1909) While Futurism tried to change the society by speeding it up, Surrealism and Dadaism focused on the disrupting power of dreams, collages and automatic texts in an attempt to articulate the new confusing reality. The avant-garde movements focused on two crucial aspects of resistance against the dominant order. Either you speed up the contradictions until resolved into new social relations, or paralyze the notions of time and of progress to disrupt the system: in short, accelerate or stop. Accelerationism became the new cool stuff in the British academia mid-90's - a new way to reflect on the shock of the system caused by the progress of the digital technological revolution. Sadie Plant and Nick Land, as the main protagonist of the early accelerationist phase, defined the subsequent use of the concept. Inspired by both of them, the contemporary accelerationists branch into two categories. Those on the left believe the contradictions in the society can be surpassed by speeding up or slowing down the social dialectics. For the right wing, the goal of accelerationism is the utter disintegration and the decomposition of the stratified social order, be it communism or liberal democracy. So, the concept of accelerationism was invariably used either to bring to surface again the old Marxian work of the negative or, to affirmatively support the speeding up of the digital capital by the new libidinal energy of the machinistic vitalism.

The right wing accelerationism seems to be the one taking more solid ground as it has become extremely popular among current political nationalists and media manipulators. For instance, the leader of Vote campaign, Dominic Cummings, uses Brexit to break down the Leviathanic system of centralized states descended from the Enlightenment Era. In the recent Channel 4 production, Brexit: The Uncivil War, Cummings was portrayed as a genius who senses the working of the negative at the core of the British society. But his methods are of a clever trickster and manipulator and, as it has increasingly become evident, he has no slightest idea what the future of Britain will hold.

In what follows, I will present few options left for the strategic and organized approach to the malaises of the modern digital society. The class revolution in the traditional Marxist way does not appear to be a viable option since the working class, as an organized force of resistance, has steadily been atomized and dispersed by the capital. Still, the dialectal intervention, in less universal terms, might offer possible exit strategies from the increasing level of the current cultural and political impasse. Mobilized and immanent in its practice, less of a strategy and more of a tactics, it might rival capital in its accelerated frenzy while retaining the force of negativity necessary for dismantling the processes of the real abstractions. In this 
sense, the avant-garde counter-representational strategies will have to be refashioned again for the sake of preventing the capital from sublating its own contradictions.

\section{SITUATIONIST'S REVOLUTION}

Written by Guy Debord, Society of the Spectacle came out as a perfect handbook for the largest social unrest in the post-war Europe. In the vein of his avant-garde predecessors, Debord formulates the dominant mode of production of the liberal capitalism under the concept of the spectacle, 'Understood in its totality, the spectacle is both the outcome and the goal of the dominant mode of production' (Debord 1994: 6). To Debord, the spectacle is the ideological representational strategy that attempts to glue the contradictions between the saturation of the culture with images and the resulting spectacularization of the social relations. The production of images in modern capitalism, he claims, has replaced the production of commodities, or the produced commodities have taken the form of images. The production of the spectacular world becomes an end in itself, as the images take their independent life: disseminated by the media, these ghost-like appearances separate us from living our lives. The spectacle as a 'visible negation of life' demands that the very reality of every individual's life is suspended. Life is subsumed under the power of the representation of it. The current social malaise of Facebook and Instagram, along with the overall separation between living your life and being trancelike fascinated by its depiction on the screen, was properly diagnosed by Debord half a century ago, 'Since the spectacle's job is to cause a world that is no longer directly perceptible to be seen but via different specialized mediations, it is inevitable that it should elevate the human sense of sight to the special place once occupied by touch; the most abstract of senses, and the most deceived, sight is naturally the most readily adaptable to present-day society's generalized abstraction.' (Debord 1994: 18) The political narrative promoting the advantages of the technological development is wrong, claims Debord: the ideology behind the promise of the libidinal liberation by the power of the image culture produces only '...social organization of a paralyzed history, of a paralyzed memory, of an abandonment of any history founded in historical time'. (Debord 1994: 18)

The growing sense that the humanity is detached from creating its own life by the abuse of the personal and collective history, created an explosive social energy on the streets of Paris, and throughout France in 1968. The making of the revolutionary graffiti on the walls of Paris, the physical blockage of the streets, the commune-like solidarity between the students and the workers, the organization of poetic readings and the dispersal of political pamphlets - were all methods taken from the long list of Sitationist's inventory. Social life got disrupted, the spectacle paralyzed; with no TV's around, people started communicating their lives, and the lives of their neighbours and friends. The practice of art, in relation to the political practice, regained its full social significance; instead of being isolated as a separate practice in the galleries, performance halls and academic departments, art became the unifying force of the society.

In the years afterwards, the spectacle learned how to control its own disruptions. It elevated the simulation of social life to the level where every attempt at resistance soon turns out to be recuperated by the matrix of simulations. By the end of the 80 's, the rise of the simulated (financial) capital and the rise of the digital era marked the dissolution of some of the core Situationist's concepts. After Baudrillard's (1998) contention that at the structural level the simulacra has effectively erased any traces of the real, Debord found it necessary to address these disturbing notions, by writing an addendum to his original book. In Comments 
on the Society of Spectacle (1998) Debord's view of the latest integrated spectacle is rather grim, 'Spectacular government, which now possesses all the means necessary to falsify the whole of production and perception, is the absolute master of memories just as it is the unfettered master of plans which will shape the most distant future.' (Debord 1998: IV) The collapse of the Eastern bloc signalled the defeat of the tendency to play on capital's contradictions. It turned out that the same contradictions worked in the communist countries as well, bringing about the dissolution of its social and political regime. On the other hand, it seemed that the contradictions got tamed and contained in the West. The negative got successfully negated. The history came to an end.

\section{THE RISE OF THE BRITISH CULTURAL STUDIES}

After the failure of the 60's revolution, Continental critical theory struggled to find new political and aesthetic articulation; soon, its ideas got transferred into the British popular culture. Punk music delivered the logic, the strategy and the techniques of Situationism, while the British Cultural Studies started dealing with the issues of street culture, fashion and music, as instances of ritualistic resistance against the Thatcher/Reagan take on liberal capitalism. University of Birmingham's Center for Contemporary Cultural Studies (CCCS) became the locus of the activity for theoreticians and students who wanted to investigate and articulate the new approach towards the British culture. CCCS was very active in the 70's and the 80 's, producing numerous books, articles, conferences and seminars and, initiating different sub-theoretical branches of investigation - the notable being the feminist, queer and race theory. In the 90's, its impact diminished in scope, but it still managed to exert powerful influence over graduate students. Sadie Plant chose one of them as part of her doctoral research, to rewrite again the history of SI. The Most Radical Gesture (1992) was not only homage to the history of avant-garde but an attempt to locate the ground for further resistance, if any. Plant confirms the pessimistic diagnosis of Debord's Comments. The restructuring of the latest forms of the spectacle leaves no room for any subversion: what is more, the system learned how to integrate the negativity, 'The gradual introduction of the avant-garde into mainstream culture provided a perfect case study of the recuperation of radical discourse.' (Plant 1992: 77) Sensing the weak spot in the system, Plant concludes that if the production of the real exceeds itself, the spectacle will evaporate into oblivion. In other words and, following the avant-garde prescription, she returns to the idea that the system should be speeded up so that in the production of the missing part (the real) it will drain its energy and resources.

In 1995, Plant took the tenure at Warwick University. There, amid the atmosphere of academic freedom, she met a group of people that not only shared the CCCS enthusiasm but were determined to push theoretical experimentation to its limits. The result was the formation of the infamous Cybernetic Culture Research Unit (Ccru). Ccru existed as a separate branch of the Philosophy Department at Warwick, creating a unique collective of lecturers and talented graduate students. The real development of Ccru happened when Plant started an intensive private and intellectual partnership with Nick Land.

The most prominent figure in the philosophical department of Warwick, the bad boy of the British Academia, Land is by many considered to be the most important British philosopher in the last 25 years. In his philosophical experimentation with the limits of the human experience, Land found in Plant a partner and a soul mate. Inspired more by Deleuze and Guattari rather than SI, Land concludes that capitalism not only survives contradictions but 
actually feeds on them. The dialectics of the negative has surpassed itself, 'Marx has been outdated by cybernetic theory. It's obvious that capitalism isn't going to be brought down by its contradictions. Nothing ever died of contradictions!' (Reynolds 2009: 8) The capital does not even need the massive administrative baggage of the neoliberal State anymore; in order to reach the escape velocity from the gravitational pull of the masses it must accelerate, faster and faster, like the jungle music of the 90's, being the perfect musical counterpoint of Ccru.

Reflecting on the increased digital abstraction of the real, Land and Plant designed the concepts of cyberpositive and hyperstition. They contend that capitalism in its present form is so overpowering that basically it '... is not a human invention, but a viral contagion, replicated cyberpositively across post-human space' (Land, Plant 1994: 4). By imitating the capitalist spectacle construct, they hope that new virtual potentials will resurface from the future, to be retroactively actualized in the present; very similar to the operation of computer viruses that will, upon activation, get amplified intensity by the positive feedback loop until they reshape the whole computer platforms in their fashion. From that perspective, cyberpositivity is basically an imitation of the acceleration practices of the capitalist's machine, but with the idea to 're-purpose' its aim and bring about its imminent collapse.

As for the use of hyperstition their vision collides. The very concept, a mixture of hype and superstition, denotes a dynamic force of 'fictions that makes themselves real', where hype stands for fast aggravated circulation, and superstition for magical narratives. Capitalism reproduces itself on the basis of fictional images; the digital media serves to endlessly produce and instantly disseminate social fantasy myths that are later actualized as reality. To fight this, Plant conceives of hyperstition as a representational weapon meant to challenge the real abstraction and the value system of the spectacle. Land, on the other hand, holds that no counter representational strategy will seriously produce any structural shock to the system. For Land reality is but a fiction; hyperstition is not a white magic but the way reality works so, why not start producing reality from the 'realm of energetic forms and entities awaiting to be conjured into existence' (Hickman 2017). Land considers capitalism to be a case of massive hyperstitional project whereby the alien forces from the future use capital as a vehicle to presuppose their existence, libidinally forcing the humanity towards machine enslavement and terminal extinction. (It is curious to note that he also claims the holy birth of Bethlehem to be another case of hyperstition.) His vision rivals Bataille's': he passionately opens himself towards the outside to learn what determines him, determining itself; at the outer edges of reason and philosophical conceptualization he joyously wills himself into Singularity where his libidinal desire will affectively be united with the machine.

To conclude, left wing accelerationism uses the capital's abstractions to energize the slumbered forces of historical change and to magically retrieve the affective potential, or spirit of the past, for future emancipation of the social relations. The right wing, on the other hand, intensively charges itself with the destabilizing power of the technological future using fictional myths to announce the rupture of the present by some future AI revolution. In short, the left opts for the revision of the old proven ideas while the right is busy generating new myths, even if they have been proven false. It comes as no surprise that the right accelerationism dominates the political imaginary nowadays.

1 Land's only published book 'Thirst for Annihilation' (1992) is a lengthy reflection on George Bataille's philosophy of excess. 


\section{NR-x AND DOMINIC CUMMINGS}

At the turn of the new century Land's philosophy resurged again. His cyberpunk glorification of the accelerated flow of technological capitalism created a community of followers among the right wing extremists. A decade ago, certain Silicon Valley political bloggers and digital entrepreneurs openly claimed that humanity cannot intellectually follow the development of the modern digital technology. They exhibited serious disrespect towards political parties, the ideas of the progress and towards any other forms of democratic alliance. Influenced by Nick Land, the Neoreactionaries, or simply NR-x, embraced accelerationism as their weapon for political dominance. Strangely enough, Land's philosophical investigation, that started as a critical research of the capital's inherent contradictions and its tendency for posthumanism, ended as the core alt-right textbook, representing the homophobic, and in some instances even racist and fascist political ideology; in the process, it unintentionally supported Trump's rise to power and created the chaos called Brexit, influencing political upstarts like Dominic Cummings.

Not a newcomer in politics, Cummings was experienced enough to be called to became the chief of the Vote Leave campaign. He immediately tried to articulate and make use of the new social contradictory reality in Britain (the noise), by freely combining the real and the imagined. He felt the fear looming across the island; fear of immigrants and of the uncertain future. Taking his additional power by the friendly support of the Silicon Valley digital infrastructure, he bombarded the public with the hysperstitional fictional stories and invented myths about EU. His goal was to affect the voters with the politics of fear. As a true right wing accelerationist, he cared for speed, not for truth. As Hickman (2019) observes, 'In a post-truth world fiction, not truth has become the new force working its magic to invade our lives with strange relations. In such a world the power to erase history is vital, dismantling the very notion of the human.' As it happened, it turned out that the mixture of fear, lack of historical consciousness and accelerated urgency was a perfect mixture to ignite the Vote Leave voters. The paradox being: Cummings is the Oxford graduate with a history degree.

\section{CONCLUSIONS}

The development and the acceleration of the financial capitalism established the dominance of the real abstraction over all aspects of modern life. Left-accelerationism, alongside speculative realism, as its philosophical support, concludes that at this stage capital is unable to offer any promise for the future: the idea of the progress seems obsolete as we are faced with the condition of the 'frenetic standstill' of the capital which, in political terms, 'produces paralyses of the political imaginary'. (Srnicek, Williams 2013) Ludditism aside, the left embraces the new technology but in a teleological way, navigating it towards a non-capital use.

Benjamin Noys, the critic that invented the term accelerationism in the first place, and the one who has been the most persistent participant of various accelerationist's debates in the last ten years, contends that the development of new imaginative 'positive feedback' outside the reach of the digital control system should be aesthetic but also a political imperative. In his essential take on accelerationism, Noys (2010) admits that there are not too many options left for the incursion of the negative into the operations of the capitalist machine. This is foremost due to the demise of the working class as the basic agency for the politics of the negative. What we are left with, according to Noys, is 'active nihilism' - an aesthetic detournement that will deliberately decompose and remake the structure of the spectacular 
capitalism. The old Situationist's practice of rearranging the textual and pictorial codes into a new absurdist assemblage seems to be the potent weapon for unmasking the process of the real abstractions. Noys calls the method 'determinate deformation' meant to reveal the framework, the skeleton and the relational grid behind the structural glaze of the real abstraction. He proposes the articulation of '...greater abstraction that leads to the rupture of real abstraction... It is a matter of probing the 'truth' of real abstractions as concrete appearances through their negation.' (2010, p.167, his emphasis) A negative imprint of the ideology behind the abstraction should expose the empty construct, holding no support in reality.

In a recent article, Slavoj Zizek (2019) warns against Land's fascination with the technological promise of the unity with the machine in a state of Singularity. He proposes the dialectical solution in a similar inverted manner: as the individual is necessary alienated in the relation to capital (positioned as the Big Other), an inverted alienation, that of the infinite by the finite individual, would 'de-sublimate' the capital and the machine from its status of Singularity and turn it into what it is - 'vast stupid machine'. There lies the power of the negative: like in a photographical negative, the $\mathrm{x}$-rayed picture shows the absence of the smooth space where capital exercises its dominance. Instead, the loss of reality support, be it history, or a human agency, leaves capital with nothing to deterritorialize, nothing to negate, but itself.

Similarly, in a political sense, Debord locates the fatal flow of the system, 'Once the running of a state involves a permanent and massive shortage of historical knowledge, that state can no longer be led strategically.' (Debord 1998: VII) Brexit is obviously the case in point, but the whole schizoid capitalism in general, being forever destined to grapple with its bad infinity, lacks historical navigation and cannot anchor itself to any specific reality. To conclude, due to its aesthetic, ontological and political deficiency, it is increasingly clear that the latest technological revolution alone will not help the inhuman capital in its quest for world domination. Williams warns that 'The continuous nature of reality escapes the quantized grasp of our present computational paradigm' (2013). In other words, by excessively producing the reality they will always fail to materialize it: digital algorithms cannot stand for the reality and will not replace the power of human creativity. That is the lesson that Land and Cummings have to learn and that is our only hope.

Received 18 October 2019

Accepted 28 December 2019

\section{References}

1. Baudrillard, J. 1998. 'Simulacra and Simulation', in Selected Writings, ed. M. Poster. San Francisco: Stanford University Press, 166-184.

2. Debord, G. 1994. Society of the Spectacle. New York: Zone Books.

3. Debord, G. 1998. Comments on the Society of the Spectacle. New York: Verso.

4. Finelli, R. 2007. 'Abstraction Versus Contradiction: Observations on Chris Arthur's The New Dialectic and Marx's "Capital", Historical Materialism 15(2): 61-74.

5. Hickman, S. C. 2016. 'Srnicek and Williams: A Postcapitalist Future', in Dr. Rinaldi's Horror Cabinet. Available at: https://socialecologies.wordpress.com/2016/02/06/nick-srnicek-and-alex-williams-on-folkpolitics-a-future-beyond-work-in-a-postcapitalist-world/

6. Hickman, S. C. 2017. 'Hyperstition: The Apocalypse of Intelligence', in Dr. Rinaldi's Horror Cabinet. Available at: https://socialecologies.wordpress.com/2017/04/24/hyperstition-the-apocalypse-of-intelligence/

7 Hickman, S. C. 2019. 'Apocalyptic Culture: Nick Land - Hyperstition at the Edge of Oblivion', in Dr. Rinaldi's Horror Cabinet. Available at: https://socialecologies.wordpress.com/2019/02/05/apocalyptic-culture-hyperstition-at-the-edge-of-oblivion/

8. Land, N.; Plant, S. 1994. Cyberpositive. Available at: https://www.sterneck.net/cyber/plant-land-cyber/ 
9. Land, N. 2011. Fanged Noumena: Collected Writings 1987-2007, eds. R. Mackay and R. Brassier. Falmouth: Urbanomic.

10. Marinetti, F. T. 1909. Futurist Manifesto. Available at: https://bactra.org/T4PM/futurist-manifesto.html

11. Marx, K. 2010. Capital. New York: Pacific Publishing Studio.

12. Noys, B. 2010. The Persistence of the Negative. Edinburgh: Edinburgh University Press.

13. Plant, S. 1992. The Most Radical Gesture. London: Routledge.

14. Reynolds, S. 2009. 'RENEGADE ACADEMIA: THE Cybernetic Culture Research Unit', in Energy Flash. Available at: https://energyflashbysimonreynolds.blogspot.com/2009/11/renegade-academia-cybernetic-culture.html

15. Sohn-Rethel, A. 1978. Intellectual and Manual Labour. London: Macmillan.

16. Srnicek, N.; Williams, A. 2013. ‘\#ACCELERATE: Manifesto for an Accelerationist Politics', in Dark Trajectories: Politics of the Outside, ed. J. Johnson. New York: Name Publications, 135-155. Available at: https://www.academia.edu/2379428

17. Toscano, A. 2008. 'The Culture of Abstraction', Theory, Culture and Society 25(4): 57-75.

18. Williams, A. 2013. 'Escape Velocities', E-flux, Journal No. 46. Available at: https://s3.amazonaws. com/arena-attachments/158008/489d34dc46224770de8822383c844a45.pdf?1380932284

19. Zizek, S. 2019. 'The Libidinal Economy of Singularity', Philosophical Salon, Los Angeles. Available at: https://thephilosophicalsalon.com/the-libidinal-economy-of-singularity/

\title{
LJUBISHA PETRUSHEVSKI
}

\section{Greitas ir negatyvus: dialektika ir posthumanizmas}

\author{
Santrauka \\ Straipsnyje apeliuojama $\mathfrak{i}$ tai, kaip televizijos drama „Breksitas. Karas be taisyklių“ \\ (Brexit: The Uncivil War) dekonstruoja moderniam kapitalizmui būdingus prieštaravi- \\ mus. Istoriškai tiek K. Marksas, tiek avangardo srovès atstovai tikejjo, kad procesų grei- \\ tinimas arba lètinimas padidins prieštaravimus tiek, kad sistema sugrius. Britų kultūros \\ teorija plètoja šị klausimą su įdomia filosofine perspektyva - koks kapitalo santykis su \\ realybès abstrakcija skaitmeniniame amžiuje. Taigi čia kalbama apie greitinimą dviem \\ besivaržančiais požiūriais - estetiniu ir politiniu: kairieji siekia išnaudoti dialektinį ne- \\ gatyvumą atskiriant technologinès pažangos greiț nuo kapitalo įsivaizdavimo, o deši- \\ nieji - produkcijos galios didinimą ittraukia atverdami posthumanizmo, mašininio ypa- \\ tingumo invaziją.
}

Raktažodžiai: avangardas, Marksas, Nick Land, Breksitas, greitinimas, realybės abstrakcija 